\title{
PENGARUH INFLASI, SUKU BUNGA, DAN NILAI TUKAR TERHADAP INDEKS HARGA SAHAM GABUNGAN PERIODE 2016 - 2018
}

\author{
a Irine Melyani, b Martha Ayerza Esra \\ Institut Bisnis dan Informatika Kwik Kian Gie \\ ayerza.esra@gmail.com
}

\begin{abstract}
The movement of stock price index is the important indicator for investors to determine whether the investor would sell, buy, or hold shares. The movement of CSPI is affected by several factor like macroeconomy. The purpose of this study was to determine the effect of inflation, interest rate, and exchange rate against CSPI. Theoretically, the effect of inflation, interest rate, and exchange rate is based on efficient market hyphothesis and signalling theory which inflation, interest rate and exchange rate provide signal to investor which affect their decision that cause change to CSPI. The type of data used in this study is secondary data with quantitative approach. The sampling is based on time series data from 2016-2018 using purposive sampling methodso that 36 samples are obtained. This research uses multiple uses multiple regression analysis method using SPSS 2.2. The results of this study indicate that during the period 2016-2018 inflation does not affect CSPI, the interest rate have negative affect on CSPI and exchange rate have positive affect on CSPI. Future research is expected to add another independent variable and extend the time range of the research to obtain ore accurate and comprehensive results.
\end{abstract}

Keywords: Inflation, Interest Rate, Exchange Rate, Composite Stock Price Indonesia

\begin{abstract}
ABSTRAK
Pergerakan IHSG menjadi indikator penting bagi para investor untuk menentukan apakah investor akan menjual, membeli, atau menahan sahamnya. Pergerakan IHSG dipengaruhi oleh berbagai faktor seperti makroekonomi. Tujuan dari penelitian ini adalah untuk mengetahui pengaruh inflasi, suku bunga, dan kurs terhadap IHSG. Secara teoritis, pengaruh inflasi, suku bunga, dan kurs didasarkan pada teori pasar efisien dan teori sinyal dimana inflasi, suku bunga, dan kurs memberikan sinyal masing-masing terhadap investor yang mempengaruhi keputusan investor sehingga terjadi perubahan pada Indeks Harga Saham Gabungan. Jenis data yang digunakan dalam penelitian ini adalah data sekunder dengan pendekatan kuantitatif. Penentuan sampel berdasar data runtut waktu periode 2016-2018 dengan menggunakan metode purpose sampling sehingga diperoleh 36 sampel. Penelitian ini menggunakan metode analisis regresi linier berganda dengan menggunakan program SPSS 2.2. Hasil penelitian ini menunjukan bahwa selama periode 2016-2018 variabel inflasi tidak memiliki pengaruh terhadap IHSG. Variabel suku bunga memiliki pengaruh negatif dan kurs memiliki pengaruh positif terhadap IHSG. Penelitian selanjutnya diharapkan dapat menambahkan variabel independen lain dan memperpanjang range waktu penelitian agar lebih akurat dan menyeluruh.
\end{abstract}

Kata Kunci: Inflasi, Suku Bunga, Nilai Tukar, Indeks Harga Saham Gabungan 


\section{PENDAHULUAN}

Data historis pergerakan saham sangat diperlukan oleh investor dalam bertransaksi di BEI. Informasi mengenai kinerja saham diringkas dalam suatu indeks yang disebut dengan indeks harga saham (stock price index) (Tandelilin, 2010:86). Indeks dalam pasar modal berfungsi sebagai indikator trend pasar artinya indeks saham memiliki fungsi untuk mengetahui keadaan pasar saat ini apakah sedang aktif atau sedang lesu. IHSG memiliki beberapa manfaat antara lain sebagai penanda arah pasar, sebagai tolok ukur kinerja portofolio, dan sebagai pengukur tingkat keuntungan (Paramasti ,2015).

Alasan dipilihnya lingkungan ekonomi makro sebagai variabel penelitian dikarenakan lingkungan makro ekonomi lebih cepat menyesuaikan diri dengan harga saham. Alasan lain dipilihnya lingkungan ekonomi makro dikarenakan keberadaan variabel makro ekonomi tidak bisa dihindari dampaknya dikarenakan variabel ekonomi makro tidak hanya mengenai satu atau dua perusahaan saja akan tetapi seluruh perusahaan yang berada di BEI bisa terkena dampak dari ekonomi makro (Samsul, 2015:200). Beberapa faktor makro ekonomi yang berpengaruh terhadap investasi di suatu negara, seperti tingkat pertumbuhan Produk Domestik Bruto, inflasi, tingkat suku bunga, nilai tukar mata uang (Tandelilin, 2010:343).

\section{KAJIAN LITERATUR}

\section{Efficient Market Hypothesis Theory}

Menurut Fama (1970) dalam Jogiyanto (2017:617), Jika harga sekuritas "mencerminkan secara penuh" informasi yang tersedia, maka ini dikatakan pasar sekuritas yang efisien Cahyadin dan Devi (2009) dalam Mailangka (2013) mengemukakan hipotesa bahwa harga pasar merupakan refleksi dari harga wajar saham dari waktu ke waktu, saat harga pasar tinggi artinya ekonomi sedang bulish, terjadi ekspansi ekonomi jadi wajar harga saham menjadi mahal. Saat harga pasar jatuh, artinya ekonomi sedang bearish, terjadi perlambatan/resesi ekonomi, jadi wajar harga saham menjadi murah.

\section{Signalling Theory ( Teori Sinyal)}

Menurut Irham (2013:100), Naik turunnya harga di pasar dibahas dalam Signaling theory, sehingga akan memberikan pengaruh pada keputusan investor terhadap informasi yang terjadi dari kondisi saham suatu perusahaan, ini memberikan efek bagi keputusan investor sebagai pihak yang menangkap sinyal tersebut.

Informasi yang di umumkan kepada publik baik yang bersifat positif maupun negatif akan ditekan oleh Teori Sinyal dan ini akan pengaruh terhadap keputusan investor dalam berinvestasi. Untuk menanggapi sinyal tersebut, mereka akan bereaksi dengan berbagai cara

\section{Inflasi}

Menurut Bodie et al ( 2014), Tingkat kenaikan harga secara umum ini dikenal dengan Inflasi dan sering diasosiasikan dengan ekonomi yang terlalu panas, yaitu ekonomi dimana kapasitas produksi lebih rendah dari permintaan barang dan jasa sehingga terjadi kenaikan harga-harga.

\section{Suku Bunga}

BI 7-Days Repo Rate artinya sikap atau stance kebijakan moneter yang ditetapkan oleh bank Indonesia dan diumumkan kepada publik (www.bi.go.id, 2018) atau lebih dikenal dengan istilah suku bunga

\section{Kurs}

Menurut Salvatore (2014:61), Harga mata uang dalam negeri dikonversikan dari mata uang asing, ini dikatakan sebagai nilai tukar 


\section{Indeks Harga Saham Gabungan}

Menurut Jogiyanto (2017:167) Pergerakan- pergerakan harga untuk saham biasa dan preferen di Bursa Efek Indonesia disebut sebagai IHSG

\section{Pengembangan Hipotesis \\ Pengaruh Inflasi Terhadap Indeks Harga Saham Gabungan}

Tingkat inflasi yang tinggi biasanya dikaitkan dengan kondisi ekonomi yang terlalu tinggi (overheated. Salah satu penyebab penurunan daya beli uang (purchasing power of money) adalah inflasi yang terlalu tinggi. Meningkatnya inflasi menjadi sinyal negatif bagi investor sehingga para investor akan melepas saham untuk menghindari resiko ketidakpastian pasar, sehingga menyebabkan turunnya Indeks Harga Saham Gabungan. H1: Inflasi berpengaruh negatif terhadap Indeks Harga Saham Gabungan

\section{Pengaruh Suku Bunga terhadap Indeks Harga Saham Gabungan}

Terjadinya perpindahan investasi dari saham ke deposito atau fixed investasi lainya, bisa saja disebabkan oleh naik nya tingkat suku bunga, sehinga meningkatkan harga kapital dan memperbesar biaya perusahaan

Menurut Tandelilin (2010:103), penurunan suku bunga akan menyebabkan harga saham naik. Hal ini terjadi karena jika suku bunga naik, maka return investasi yang terkait dengan suku bunga (misalnya deposito) juga akan naik. Kondisi seperti ini bisa menarik minat investor yang sebelumnya berinvestasi di saham untuk memindahkan dananya dari saham ke dalam deposito $\mathrm{H} 2$ : Suku Bunga berpengaruh negatif terhadap Indeks Harga Saham Gabungan

\section{Pengaruh Nilai Tukar Terhadap Indeks Harga Saham Gabungan}

Laba suatu perusahaan dipengaruhi oleh perbandingan nilai tukar rupiah terhadap mata uang lainnya karena perusahaan yang menggunakan bahan produksi dari luar negeri akan mengalami peningkatan nilai hutang apabila nilai rupiah terhadap mata uang asing menurun atau terdepresiasi. Investasi suatu perusahaan juga sangat dipengaruhi oleh nilai tukar rupiah karena apabila pasar modal kurang menarik daripada pasar valas maka umumnya investor akan beralih investasi ke pasar valas (Manurung, 2016).

H3 : Nilai Tukar berpengaruh negatif terhadap Indeks Harga Saham Gabungan.

\section{METODE}

Objek dari penelitian ini menggunakan data kuantitatif. Data yang digunakan adalah Tingkat Inflasi, Nilai Kurs, Suku Bunga selama periode Januari 2015 - Desember 2018. Analisis data dalam penelitian ini menggunakan regresi data time series dengan jumlah 36 observasi.

\section{Variabel Penelitian}

a. Indeks Harga Saham Gabungan

IHSG yang digunakan dalam penelitian ini adalah nilai penutupan akhir bulan periode Januari 2016 - Desember 2018 yang diperoleh dari www.yahoofinance.com

b. Inflasi

Tingkat inflasi yang digunakan dalam penelitian ini adalah tingkat inflasi selama periode Januari 2016-Desember 2018 dengan pengukuran dalam satuan persen (\%). Data diperoleh dari www.bi.go.id.

c. Suku Bunga

Suku Bunga yang digunakan dalam penelitian ini adalah suku bunga BI Rate selama periode Januari 2016 - Desember 2018. Data diperoleh dari www.bi.go.id

d. Kurs 
Data yang digunakan dalam penelitian ini adalah kurs rupiah terhadap dollar Amerika Serikat selama periode Januari 2016 - Desember 2018 dengan kurs yang digunakan yaitu kurs tengah yang diperoleh dari website Bank Indonesia dengan rumus :

Kurs Tengah $=\frac{\text { Kurs Jual }+ \text { Kurs B Beli }}{2}$

\section{Teknik Pengumpulan Data}

Dalam penelitian ini data yang digunakan adalah data sekunder, yaitu data yang berdasar dari sebuah sumber. Sumber diambil dari data-data statistik yang diterbitkan oleh Bank Indonesia dan Yahoo Finance. Data yang digunakan adalah time series berbentuk bulanan dari Januari 2016 - Desember 2018. Metode yang digunakan adalah internet research.

\section{Teknik Pengambilan Sampel}

Peneliti mengumpulkan sampel dengan menggunakan metode judgement sampling, dimana peneliti menentukan sampel berdasar kriteria tertentu. Kriteria yang digunakan dalam pengumpulan sampel adalah : data bulanan selama periode 2016-2018.

\section{Teknik Analisis Data}

Teknik analisis yang dilakukan adalah :

1. Analisis Statistik Deskriptif

Adalah alat statistik untuk mendeskripsikan atau memberi gambaran terhadap objek yang diteliti melalui data sampel atau populasi sebagaimana adanya, tanpa melakukan analisis dan membuat kesimpulan yang berlaku umum dari data tersebut. Statistik deskriptif memberikan gambaran atau deskripsi suatu data yang dilihat dari mean, nilai minumun, nilai maksimum, dan standar deviasi.

2. Uji Asumsi Klasik

Adalah model regresi yang digunakan untuk memastikan kelayakan dalam penelitian ini, dimana data tersebut digunakan secara normal, bebas dari autokorelasi, multikolinieritas, dan heterokidestisitas.

a. Uji Normalitas

uji normalitas berguna untuk menentukan apakah dalam model regresi, variabel penggangu atau residual berdistribusi normal. Data akan berdistribusi normal apabila memiliki nilai sig $>0,05$ dengan menggunakan uji Kolmogorov Smirnov.

b. Uji multikolinieritas

Uji multikolinieritas bertujuan untuk menguji apakah model regresi ditemukan adanya korelasi antar variabel bebas (independen). Untuk mengetahui ada tidaknya multikolinieritas dalam model regresi adalah dengan melihat dari Tolerance atau VIF (Variance Inflation Factor) dari masing-masing variabel. Suatu model regresi tidak terdapat multikolinieritas apakah memiliki VIF $<10$ dan nilai toleransi $>0,1$ berarti terdapat multikolinieritas di dalam model regresi.

c. Uji Autokorelasi

Uji Autokorelasi bertujuan menguji dalam model regresi linier ada korelasi antara kesalahan penganggu pada periode $t$ dengan kesalahan penganggu pada periode t-1 (sebelumnya). Bila nilai DW terletak antara batas atas atau degree upper (du) dan (4-du), maka koefisien autokorelasi sama dengan 0 berarti tidak ada autokorelasi.

d. Uji heteroskedastisitas

Uji heteroskedastisitas bertujuan untuk menguji apakah dalam model regresi terjadi ketidaksamaan variance dari residual satu pengamatan ke pengamatan yang lain. Data tidak terjadi heteroskedastisitas apabila memiliki sig > 0,05

3. Analisis Regresi Ganda 
Analisis regresi ganda bertujuan untuk mempelajari hubungan antara dua variabel atau lebih. $Y=\alpha+\beta_{\text {inflasi }} X_{\text {inflasi }}+\beta_{\text {suku bunga }} X_{\text {Suku bunga }}+$ $\beta_{\text {kurs }} X_{k u r s}+\epsilon$

Dimana:

$$
\begin{aligned}
& Y=\text { Indeks Harga Saham } \\
& \text { Gabungan } \alpha=\text { Konstanta } \\
& \epsilon=\text { Standart Error }
\end{aligned}
$$

4. Uji F

Jika sig $F<$ nilai $\alpha(0,05)$, maka tolak Ho,artinya variabel independen secara simultan berpengaruh terhadap variabel dependen.

Jika sig $F>$ nilai $\alpha(0,05)$, maka tidak tolak Ho,artinya variabel independen secara simultan berpengaruh terhadap variabel dependen.

5. Ujit

Uji t statistik dilakukan untuk mengetahui apakah masing-masing variabel independen secara individual berpengaruh terhadap variabel dependen.

Jika sig.t $\leq \alpha$, Ho ditolak (variabel independen secara individu berpengaruh terhadap variabel dependen).

Jika sig.t $>\alpha$, Ho tidak ditolak (variabel independen secara individu tidak berpengaruh terhadap variabel dependen).

6. Uji Koefisien Determinasi

Koefisien Determinasi $\left(R^{2}\right)$ digunakan untuk mengukur seberapa jauh kemampuan model dalam menerangkan variabel-variabel dependen.

\section{HASIL DAN PEMBAHASAN}

\section{Hasil \\ Uji Statistik Deskriptif}

Berikut adalah hasil uji statistik deskriptif dari setiap variabel:

Tabel 1

\section{Hasil Statistik Deskriptif}

\begin{tabular}{|l|l|l|l|l|l|}
\hline & N & Minimum & Maximum & Mean & $\begin{array}{l}\text { Std. } \\
\text { Devinatio } \\
n\end{array}$ \\
\hline IHSG & 36 & 4615 & 6606 & 5593 & 479 \\
\hline Inflasi (\%) & 36 & 2.79 & 4,45 & 3,51 & 0,44 \\
\hline $\begin{array}{l}\text { Suku } \\
\text { Bunga(\% } \\
\text { Kurs(Rp/\$) }\end{array}$ & 36 & 4,25 & 7,25 & 5,22 & 0,93 \\
\hline Kurs(Ro & 13017 & 15179 & 13650 & 563 \\
\hline
\end{tabular}

Pada tabel 1 diatas, Variabel Indeks Harga Saham Gabungan tertinggi pada harga 6606 di bulan Januari 2018, dan nilai terendah pada harga 4615 di bulan Januari 2016 dengan standar deviasi 475 dan mean sebesar 5593 artinya data kurang bervariasi karena nilai standar deviasi lebih kecil daripada mean.

Variabel Inflasi tertinggi pada angka 4,45\% yaitu pada bulan Maret 2016, dan nilai terendah pada angka 2,79\% di bulan Agustus 2016 dengan standar deviasi 0,444 dan mean sebesar 3,51, hal ini menunjukkan data yang kurang bervariasi dilihat dari standar deviasi yang lebih kecil daripada mean.

Variabel Suku Bunga tertinggi pada angka 7,25\% di bulan Januari 2016, dan nilai terendah pada angka 4,25\% di bulan September 2017 sampai dengan April 2018 dengan 
standar deviasi 0,926 lebih kecil dibandingkan nilai mean 5.22 yang menunjukkan data yang kurang bervariasi.

Variabel Nilai Tukar tetinggi pada harga 15179 di bulan Oktober 2018,dan nilai terendah pada harga 13017 di bulan Oktober 2016 dengan standar deviasi 563 lebih kecil dibandingkan nilai mean sebesar 13650 menunjukkan data yang kurang bervariasi.

\section{Uji Asumsi Klasik}

Tabel 2

Hasil Uji Asumsi Klasik

\begin{tabular}{|l|c|c|c|c|}
\hline \multirow{2}{*}{ Variabel } & \multicolumn{4}{|c|}{$\begin{array}{c}\text { Jenis } \\
\text { Pengujian }\end{array}$} \\
\cline { 3 - 4 } & Normalitas & $\begin{array}{c}\text { Multikolienarita } \\
\text { s }\end{array}$ & $\begin{array}{c}\text { Heteroskedastisit } \\
\text { as }\end{array}$ & Autokorelasi \\
\hline Inflasi & \multirow{2}{*}{0,127} & 1,238 & 0,978 & \multirow{2}{*}{1,987} \\
\cline { 1 - 3 } $\begin{array}{l}\text { Suku } \\
\text { Bung } \\
\text { a }\end{array}$ & 1,093 & 0,369 & \\
\hline Kurs & & 1,255 & 0,954 & \\
\cline { 3 - 4 } & & & & \\
\hline
\end{tabular}

Berdasarkan hasil tabel 2, dapat dilihat bahwa nilai VIF untuk keseluruhan variabel bebas berada dibawah 10 sehingga dapat dikatakan tidak terjadi masalah Multikolinearitas. I. Dari hasil tabel 2, nilai DW test sebesar 1.987 yang berada diantara $1.654-2.346$ sehingga dapat disimpulkan bahwa tidak terjadi autokorelasi.dari tabel 2, nilai signifikan dari tiap variabel bebas terhadap residu menunjukkan hasil yang lebih besar dari $5 \%$, maka dapat disimpulkan tidak terjadi persoalan heteroskedastisitas dalam model. Dan dari tabel 2 memperlihatkan besarnya signifikan berada di atas 0,05 yang berarti data berdistribusi normal.

\section{Uji Statistik}

Dari hasil pengolahan didapatkan model sebagai berikut :

IHSG $=1217,88-18,10 \mathrm{INF}-373,36 \mathrm{SB}+0,468$ Kurs

Dari persamaan regresi berganda di atas dapat dijelaskan sebagai berikut:

a. Nilai konstanta sebesar 1217,88 . Hal ini menunjukkan bahwa apabila variabel inflasi, suku bunga, dan kurs nilainya nol maka nilai IHSG adalah 1217,88.

b. Nilai koefisien regresi inflasi adalah sebesar 18,10. Hal ini menunjukkan bahwa apabila nilai inflasi meningkat 1 satuan maka nilai variabel IHSG akan mengalami penurunan sebesar 18,10 dengan asumsi variabel independen lainnya konstan. Hal ini menunjukkan hubungan yang berlawanan. Jika variabel inflasi meningkat maka IHSG akan menurun, begitupula sebaliknya.

c. Nilai koefisien regresi suku bunga adalah sebesar 373,63. Hal ini menunjukkan bahwa apabila nilai suku bunga meningkat 1 satuan maka nilai variabel IHSG akan mengalami penurunan sebesar 373,63 dengan asumsi variabel independen lainnya konstan. Hal ini menunjukkan hubungan yang berlawanan. Jika variabel suku meningkat maka IHSG akan menurun, begitupula sebaliknya.

d. Nilai koefisien regresi kurs adalah sebesar 0,468. Hal ini menunjukkan bahwa apabila variabel kurs meningkat 1 satuan maka nilai variabel IHSG akan mengalami kenaikan sebesar 0,468 dengan asumsi variabel independen lainnya konstan. Hal ini menunjukkan hubungan yang searah. Jika variabel kurs meningkat maka IHSG akan meningkat, begitupula sebaliknya. 


\section{Analisis Determinasi}

$\left(R^{2}\right)$

Tabel 3

Hasil Analisis

Determinasi

\begin{tabular}{|c|c|}
\hline Model & Adjusted \\
& $\mathrm{R}^{2}$ \\
\hline 1 & 0,673 \\
\hline
\end{tabular}

Berdasarkan Tabel 3, 5 diketahui bahwa nilai adjusted $\mathrm{R}^{2}$ menunjukkan angka 0,673. Hal ini menunjukkan bahwa variabel dependen (Indeks Harga Saham Gabungan) sebesar $67,3 \%$ dapat dijelaskan oleh variabel independen.

\section{Pembahasan}

Tabel 4

PengujianHipotesis

\begin{tabular}{|l|r|r|r|}
\hline \multirow{2}{*}{ Model } & \multicolumn{2}{|l|}{$\begin{array}{l}\text { Unstandardized } \\
\text { Coefficient }\end{array}$} & \multicolumn{2}{c|}{$\mathrm{T}$} & \multicolumn{2}{c|}{ Sig } \\
\cline { 2 - 3 } & $\mathrm{B}$ & & 0,394 \\
\hline (Constant) & 1217,88 & 0,864 & 0,876 \\
\hline Inflasi & $-18,096$ & $-0,158$ & 0 \\
\hline Suku Bunga & $-373,364$ & $-7,202$ & 0 \\
\hline Kurs & 0,468 & 5,129 & \\
\hline
\end{tabular}

\section{Pengaruh Inflasi terhadap Indeks Harga Saham Gabungan}

Koefisien regresi dalam penelitian ini untuk variabel inflasi sebesar $-0,017$ dan nilai $t$ hitung sebesar $-0,158$ dan nilai ttabel 2,035 dan nilai signifikansi sebesar 0,876. karena nilai t hitung $<$ ttabel dan signifikansinya lebih besar dari 0,05 maka hasil ini menunjukkan bahwa inflasi berpengaruh negatif dan tidak signifikan terhadap Indeks Harga Saham Gabungan. Dengan demikian hipotesis dalam penelitian ini ditolak.

Hasil penelitian ini mendukung penelitian yang dilakukan oleh Asmara (2018) dan Harsono dan Wonokinasih (2018) , bahwa inflasi tidak berpengaruh signifikan terhadap Indeks Harga Saham Gabungan. Menurut peneliti, hubungan tidak signifikan ini disebabkan selama periode penelitian tingkat inflasi yang terjadi selalu dibawah $10 \%$ per tahun

\section{Pengaruh Suku Bunga terhadap Indeks Harga Saham Gabungan}

Suku bunga berpengaruh negatif terhadap Indeks Harga Saham Gabungan, ini adalah Hipotesis kedua dalam penelitian ini. Hasilnya koefisien regresi untuk variabel suku bunga (SB) sebesar $-0,728$ dan nilai t hitung sebesar $-7,202$, nilai ttabel 2,035 dan nilai signifikansinya sebesar 0,000 . Karena nilai t hitung < ttabel dan signifikansinya lebih kecil dari 0,05 maka hasil ini menunjukkan bahwa suku bunga berpengaruh negatif dan signifikan terhadap Indeks Harga Saham Gabungan. Dengan demikian hipotesis dalam penelitian ini diterima.

Ini sesuai dengan teori Tandelilin (2001:48) dalam Ardelila \& Saparila (2018), yaitu perubahan suku bunga akan memengaruhi harga saham secara terbalik, cateris paribus. Cateris paribus diartikan jika suku bunga meningkat, maka harga saham akan turun, cateris 
paribus, dan sebaliknya. Penelitian lainnya yang mendukung suku bunga berpengaruh negatif dan signifikan terhadap IHSG dilakukan oleh Listriono dan Nuraina (2015) dan Asmara (2018).

\section{Pengaruh Kurs terhadap Indeks Harga Saham Gabungan}

Kurs berpengaruh negatif terhadap Indeks Harga Saham Gabungan, ini adalah Hipotesis ke tiga dalam penelitian ini. Diperoleh koefisien regresi untuk variabel kurs sebesar 0,555 dan nilai t hitung sebesar 5,129 nilai ttabel 2,035 dan nilai signifikansinya sebesar 0,000 . Karena nilai t hitung $>$ ttabel dan signifikansinya lebih kecil dari 0,05 maka hasil ini menunjukkan bahwa kurs berpengaruh positif dan signifikan terhadap Indeks Harga Saham Gabungan. Dengan demikian hipotesis dalam penelitian ini ditolak.

Ini sesuai dengan hasil penelitian yang dilakukan Maurina (2015). Menurut peneliti, hal ini terjadi karena penurunan nilai tukar rupiah mengakibatkan makin murahnya produk ekspor asal Indonesia di pasar mancanegara. Hal ini akan menyebabkan meningkatnya permintaan akan produk ekspor Indonesia. Dampak positif dari melemahnya nilai tukar rupiah dirasakan oleh perusahaan ataupun pelaku bisnis yang berorientasi ekspor. Turunnya nilai tukar rupiah memungkinkan eksportir menerima profit margin yang semakin lebar apabila eksportir tidak mengurangi harga jual.

\section{SIMPULAN}

Simpulan yang didapatkan dari penelitan ini sebagai berikut: Inflasi tidak berpengaruh terhadap Indeks Harga Saham Gabungan, sedangkan Suku Bunga berpengaruh negatif terhadap Indeks Harga Saham Gabungan dan Kurs berpengaruh positif terhadap Indeks Harga Saham Gabungan di Indonesia pada periode 2016 - 2018

\section{REFERENSI}

Asmara, Wahyu Putra and I. Putu Wahyu Putra Asmara. 2018. "Pengaruh Pengaruh Variabel Makro Ekonomi Terhadap Indeks Harga Saham Gabungan." E-Jurnal Manajemen Universitas Udayana 7(3):1399-1420.

Ayu, I. Gst and Eka Damayanthi. 2013. "Analisis Perbedaan Tingkat Kesehatan

Bank Berdasarkan RGEC Pada Perusahaan Perbankan Besar dan Kecil." E-Jurnal

Akuntansi Universitas Udayana

5.2 (2013): 483-496 2(I Dewa Ayu Diah Esti Putri1 I Gst. Ayu Eka

Damayanthi2):483-96.

Bodie, Z., et al. (2014). Manajemen Portofolio dan Investasi Edisi 9 Buku 1. Jakarta:

Salemba Empat.

Darmajdi, Tjiptono dan Hendy M, Fakhruddin. 2012. Pasar Modal di Indonesia(Pendekatan

Tanya Jawab). Jakarta: Salemba Empat.

Firdaus, Ginanjar. 2015. "Analisis Pengaruh Nilai Tukar Dollar/Rupiah, Harga Emas Dunia, Harga Minyak Dunia, Indeks DJIA, Indeks Nikkei, Pembelian Bersih Asing Terhadap Indeks Harga Saham Gabungan di Bursa Efek Indonesia Periode Tahun 2003-2013." 1-23. 
Ghozali, Imam, 2018. Aplikasi Analisis Multivariate Dengan Program IBM SPSS. Semarang : BP UNDIP.

Handiani, Sylvia. 2014. "Pengaruh Harga Emas Dunia, Harga Minyak Dunia Dan

Nilai Tukar Dolar Amerika/Rupiah Terhadap Indeks Harga Saham Gabungan Pada Periode 2008-2013." E-Journal Graduate Unpar 1(1):85-93.

Hartono, Jogiyanto. 2010, Teori Portofolio dan Analisis Investasi. Yogyakarta :

BPFE UGM. Harsono, Ardella Rezeki and Saparila Wonokinasih. 2018. "Pengaruh Inflasi, Suku Bunga,

Bursa

Dan NilaiTukar Rupiah Terhadap INdeks Harga Saham Gabungan (Studi Pada

Efek Indonesia Periode 2009-2013 )." Jurnal Administrasi Bisnis 60(2):103-8.

Gede, Luh, Sri Artini, Nyoman Tri Aryati, Ni Putu, and Ayu Darmayanti. 2017.

"Pasar Saham Dunia Dengan Bursa Efek Indonesia." Jurnal Manajemen, Strategi Bisnis

Dan Kewirausahaan 11(2):128-35

Listriono, Kukuh and Elva Nuraina. 2015. "Peranan Inflasi, Bi Rate, Kurs Dollar

(Usd/ldr) Dalam Mempengaruhi Indeks Harga Saham Gabungan (lhsg).” Jurnal Dinamika Manajemen 6(1):73-83.

Mailangka, Jeina. 2013. "Integrasi Pasar Modal Indonesia Dan Beberapa Bursa Di

Dunia (Periode Januari 2013 - Maret 2013)." Journal EMBA 1(9):724.

Manurung, Ria. 2016. "Pengaruh Inflasi, Suku Bunga Dan Kurs Terhadap Indeks

Harga Saham Gabungan Pada Bursa Efek Indonesia." Jurnal Ekonomi 19(4):148-56.

Maurina, Yenita. 2015. "Pengaruh Tingkat Inflasi, Kurs Rupiah dan Tingkat Suku

Bunga BI Rate Terhadap IHSG (Studi Pada Bursa Efek Indonesia Periode 2010-2014)."

Jurnal Administrasi Bisnis (JAB) 27(2):2-7.

Ningsih, Meidiana Mulya and Ikaputra Waspada. 2018. "Pengaruh BI Rate dan

Inflasi Terhadap Indeks Harga Saham Gabungan (Studi Pada Indeks Properti, Real Estate,

Dan Building Construction, Di BEI Periode 2013 - 2017)." Jurnal MANAJERIAL 17(2):247.

Ni Wayan Sri Asih Masithah Akbar. 2016. "Analisis Pengaruh Inflasi, Suku Bunga,

Nilai Tukar (Kurs) Dan Pertumbuhan Produk Domestik Bruto (Pdb) Terhadap Indeks Harga

Saham Gabungan (lhsg) Studi Kasus Pada Perusahaan Properti Yang Terdaftar Di Bursa

Efek Indonesia." Jurnal Manajemen Dan Akuntansi 17(1):43-52.

Nopirin. 2011. Ekonomi Moneter Buku II. Yogyakarta: BPFE

Oktavian, Ahmad Fauzi. 2016. Pengaruh Kurs Dollar US dan Tingkat Suku Bunga

SBI Terhadap Return Saham ( Studi Empiris Pada Perusahaan LQ45 yang Terdaftar di

Bursa Efek Indonesia Tahun 2010 - 2014. Skripsi

Paramastri, Krissa. 2015. Analisis Determinan Indeks Harga Saham Gabungan (Composite Index) di Bursa Efek Indonesia Periode 2011-2013 SKRIPSI. Vol. 151.

Salim, Jul Fahmi. 2017. "Pengaruh Faktor Dalam Dan Luar Negeri Terhadap Indeks Harga Saham Gabungan (Ihsg) Di Indonesia." Jurnal Ekonomi Dan Kebijakan Publik Indonesia 4(1):35-48.

Empat.

Salvatore, Dominick. (2014). Ekonomi Internasional (Edisi 9). Jakarta: Salemba 
Sudarsana, Ni Made Anita Dewi and Ica Rika Candraningrat. 2013. "Pengaruh Suku Bunga SBI, Nilai Tukar, Inflasi, dan Indeks Dow Jones Terhadap Indeks Harga Saham Gabungan di BEI." X 125(4):3291-3308.

Sudirman, Sudirman. 2018. "Pengaruh Perubahan Nilai Tukar Rupiah Tengah US Dollar Terhadap Indeks Harga Saham Gabungan (IHSG) Di Bursa Efek Indonesia." A/Buhuts 14(01):1-17.Bandung

Tandelilin, Eduardus. 2010. Portofolio dan Investasi Teori dan Aplikasi. Edisi pertama. Yogyakarta :Kanisius

Taufiq, M. and Batista Sufa Kefi. 2015. "Pengaruh Inflasi, Bi Rate Dan Kurs Terhadap Indeks Harga Saham Gabungan." Pengaruh Inflasi, Bi Rate Dan Kurs Terhadap Indeks Harga Saham Gabungan 1-14.

https://www.bi.go.id https://finance.yahoo.com/ 